\title{
Evaluation of antibacterial and antifungal activity of ethanolic extract of Cochlospermum regium (Cochlospermaceae) leaf, a medicinal plant from the Cerrado of Brazil
}

\author{
José Lourenço dos Santos Cunha E Silva ${ }^{1 *}$, Bruna de Paula Bicudo ${ }^{1}$, Allan Belarmino Rodrigues', \\ Milena Mariano Mendonça', Rodrigo Raghiant Borges ${ }^{1}$, Adriana Araújo de Almeida ${ }^{2}$, Kelly Mari Pires de Oliveira ${ }^{1}$
}

From 5th Congress of the Brazilian Biotechnology Society (SBBIOTEC)

Florianópolis, Brazil. 10-14 November 2013

\section{Background}

Bioprospecting of medicinal plants is a promising activity on biotechnology researches and detection of new compounds with biological activities of interest in health. Studies on medicinal plants of the brazilian Cerrado, still limited across the wide biodiversity found in this biome, it is an important source for the treatment several diseases, including fungal and bacterial infections [5]. Cochlospermum regium (Cochlospermaceae), popularly known as "algodãozinho do cerrado" or "algodãozinho-do-campo", is a plant used in brazilian folk medicine. Among the various medicinal properties attributed to the plant stands out its use to treat diseases of infectious etiology as well as inflammation [3]. The purpose of this study was to evaluate the antibacterial and antifungal activity of the leaf extract Cochlospermum regium against Gram-positive Staphylococcus aureus ATCC 29213, Enterococcus faecalis ATCC 51299, Gram-negative bacteria Escherichia coli ATCC 25922 and Pseudomonas aeruginosa ATCC 27853, and against the yeast Candida albicans ATCC 90028, Candida tropicalis ATCC 750, Candida glabrata ATCC 2001, Candida krusei ATCC 6558.

\section{Methods}

To microbiological evaluation, the techniques used were Minimum Inhibitory Concentration (MIC), Minimum Fungicidal Concentration (MFC) and Minimum Bactericidal Concentration $(\mathrm{MBC})$. The leaves were collected at

\footnotetext{
${ }^{1}$ Faculty of Biological and Environmental Sciences, Federal University of Grande Dourados, Unit II: Highway Dourados - Itahum, Km 12; 79.804-970; Dourados, MS, Brazil

Full list of author information is available at the end of the article
}

farm Santa Madalena (S $22^{\circ} 08$ '18.3” / W $055^{\circ} 08$ '23. $\left.7^{\prime \prime}\right)$ in December 2012. Then were evaporated in rotaevaporator and lyophilized preparation of the ethanol extract. The minimum inhibitory concentration (MIC) of the extract was determined by broth microdilution according to the recommendations of CLSI (Clinical and Laboratory Standards Institute) [2]. For evaluation of the fungicide was used Sabouraud Dextrose Agar (Difco) and bactericidal Mueller Hinton Agar (Difco). It is considered that the activity of the extracts tested in MIC is less than $100 \mu \mathrm{g} / \mathrm{mL}$, antimicrobial activity will be assessed good; if for the antimicrobial activity of 100 to $500 \mu \mathrm{g} / \mathrm{mL}$ is considered medium; from 500 to $1000 \mu \mathrm{g} /$ $\mathrm{mL}$ the antimicrobial activity is considered weak; and over $1000 \mu \mathrm{g} / \mathrm{mL}$ the extract is considered inactive [1].

\section{Results and conclusions}

Based on these criteria, the ethanol extract of leaf showed good activity against the C. krusei $(64 \mu \mathrm{g} / \mathrm{mL})$, Enterococcus faecalis $(4 \mu \mathrm{g} / \mathrm{mL})$, Escherichia coli $(8 \mu \mathrm{g} /$ $\mathrm{mL}$ ) and an acceptable effect to Staphylococcus aureus $(512 \mu \mathrm{g} / \mathrm{mL})$ and inactivates action for C. glabrata (1024 $\mu \mathrm{g} / \mathrm{mL}$ ). But no effect was opposite C. albicans, C. tropicalis and Pseudomonas aeruginosa. C. krusei is a yeast with great medical relevance and cause of candidemia in adults, especially in hospitalized patients / debilitated. The results are interesting as they show that C. krusei shows a greater intrinsic resistance to the drug fluconazole, which is considered a standard medication and one of the most prescribed antimicrobial [4], and showed a reasonable resultof the antimicrobial potential against the bacteria Enterococcus faecalis and Escherichia coli 
may be an alternative for treatment of infections caused by them. This study confirms the antimicrobial activity of Cochlospermum regium and indicates that it can be a potential candidate for the development of new therapies for the treatment of infections.

\section{Acknowledgements}

To Federal University of Grande Dourados (UFGD) and Foundation Support to Development of Education, Science and Technology of the State of Mato Grosso do Sul (FUNDECT-MS).

\section{Authors' details}

${ }^{1}$ Faculty of Biological and Environmental Sciences, Federal University of Grande Dourados, Unit II: Highway Dourados - Itahum, Km 12; 79.804-970; Dourados, MS, Brazil. ${ }^{2}$ Faculty of Health Science, Federal University of Grande Dourados, Unit II: Highway Dourados - Itahum, Km 12; 79.804-970; Dourados, MS, Brazil.

Published: 1 October 2014

\section{References}

1. Araújo MG, Hilário F, Nogueira LG, Vilegas W, Santos LC, Bauab TM: Chemical constituents of the methanolic extract of leaves of Leiothrix spiralis Ruhland and their antimicrobial activity. Molecules 2011, 16(12):10479-10490.

2. Clinical and Laboratory Standards Institute (CLSI): Reference method for broth dilution antifungal susceptibility testing of yeasts: approved standard M27-A3. Wayne: Clinical and Laboratory Standards Institute; 3 2008.

3. Cunha-Laura AL, Oliveira RJ, de Barros ALC, de Siqueira JM, do Carmo Vieira M, Auharek SA: Maternal exposure to Cochlospermum regium: a toxicological evaluation. Brazilian Jounal of Pharmacognosy 2013, 23(2).

4. Scotti L, Scotti MT, de Oliveira LimaE, da Silva MS, do Carmo Alves de Lima M, da Rocha Pitta I, de Moura RO, de Oliveira JGB, da Cruz RMD, Mendonça FJB JR: Experimental methodologies and evaluations of computer-aided drung design methodologies applied to a series of 2-aminothiophene derivatives with antifungical activities. Molecules 2012, 17(3):2298-2315

5. Strobel G, Daisy B: Bioprospecting for Microbial Endophytes and Their Natural Products. Microbiology and Molecular Biology Reviews 2003, 67(4):491-502.

doi:10.1186/1753-6561-8-S4-P72

Cite this article as: E Silva et al.: Evaluation of antibacterial and antifungal activity of ethanolic extract of Cochlospermum regium (Cochlospermaceae) leaf, a medicinal plant from the Cerrado of Brazil. BMC Proceedings 2014 8(Suppl 4):P72.

\section{Submit your next manuscript to BioMed Central and take full advantage of:}

- Convenient online submission

- Thorough peer review

- No space constraints or color figure charges

- Immediate publication on acceptance

- Inclusion in PubMed, CAS, Scopus and Google Scholar

- Research which is freely available for redistribution

Submit your manuscript at www.biomedcentral.com/submit
Biomed Central 